Mots. Les langages du politique

\title{
The authoritative discourse in European Commission press releases (2011-2013)
}

Oana Marina Panait

\section{OpenEdition}

12 Journals

Electronic version

URL: https://journals.openedition.org/mots/21843

DOI: $10.4000 /$ mots. 21843

ISSN: 1960-6001

This article is a translation of:

Déceler le discours d'autorité dans les communiqués de presse de la Commission européenne

(2011-2013) - URL : https://journals.openedition.org/mots/21824 [fr]

Publisher

ENS Éditions

Printed version

Date of publication: 31 December 2014

ISBN: 978-2-84788-544-6

ISSN: 0243-6450

Electronic reference

Oana Marina Panait, "The authoritative discourse in European Commission press releases

(2011-2013)", Mots. Les langages du politique [Online], 106 | 2014, Online since 30 June 2015,

connection on 23 April 2022. URL: http://journals.openedition.org/mots/21843 ; DOI: https://doi.org/ $10.4000 /$ mots. 21843

This text was automatically generated on 23 April 2022

(c) ENS Éditions 


\title{
The authoritative discourse in European Commission press releases (2011-2013)
}

\author{
Oana Marina Panait
}

1 The non-compliance of European states with the European law application process, in particular regarding its transposition into domestic law and the implementation of European directives, is not a new phenomenon. It has been subject of debate in scientific literature, mainly through two different approaches. Research initially focused on the issue of European state non-compliance with the process of transposition and implementation of European law (Kaeding, 2006; Thomson et al., 2007; Guigner, 2011). Other research has since strived to understand the actions and strategies used by the European Commission (EC) to combat state infringements in this area (Tallberg, 2002; Steunenberg, 2010). In its annual reports on the application of European Union (EU) law ${ }^{1}$ - as well as in the reform of the management of member state infringements initiated in 2007, adapted and finalized in $2011^{2}-$, the EC reports on the implementation of European law by member states.

2 In this context, the press releases published by the Commission are interpreted as the expression of "name and shame" strategies (Tallberg, 2002; Steunenberg, 2010). Such an approach implies that the purpose of these press releases is to put pressure on states to persuade them to return to the "right path". However, we consider that this interpretation of the objectives of the press releases does not take into account the fact that any political action must be analysed in its social and ideological dimensions (Gobin, Deroubaix, 1989). Moreover, the press release is first and foremost a political speech, whose analysis should take into account "the situation of interaction" between the transmitter and the receiver(s) (de Chanay, Turbide, 2011, p. 5)3. We argue that this analysis should be completed and should take into account the existence of other objectives that these releases could fill. The Commission is not only an "agent" in the normative sense of the term, that is to say, a simple neutral actor who ensures compliance and proper implementation of European law and its derived law. The 
Commission is also a political actor (Steunenberg, 2010, p. 360). The political nature of the EC's role is not only reflected in the control mechanism used to combat state infringements, but also in the intended objectives of the press releases. To grasp a more complex picture of it, we have analysed a corpus of 77 press releases issued between September 2011 and September 2013, through which the EC expresses its position on the process of transposition and implementation of EU law by member states.

3 The present paper analyses the content and the strategic objectives of the political discourse of the European Commission on the process of transposition and implementation of EU law by European states. First of all, it points out the legal mechanisms applied by the EC to call to order the noncompliant states - meaning the appropriation of EU legislation. Then, the paper considers the Commission's press releases as instruments whose effects would be to influence the behavior of recalcitrant states and which, in the public sphere, is a denunciation strategy. This strategic instrument takes the form of an authoritative discourse whose content has normative, organized and structured character. Finally, the paper highlights that this strategic instrument has also other complementary objectives: strengthening the fundamentals of the European project, dissuasion and prevention, legitimization of the action undertaken by the EC before the European citizens and power consolidation in front of EU member states.

\section{Process of transposition and implementation of EU law by the member states}

The legal framework that provides for the need to transpose and implement European directives is the Treaty on the Functioning of the EU (TFEU)4: "The directive links any member state to the result to be achieved, while leaving the national authorities the choice of form and methods" (art. 288). The same Treaty establishes, in its article 297, that member states are obliged to take "all necessary measures of domestic law for the implementation of the legally binding acts of the Union". Should member states fail to comply with EU law, the EC has the discretionary power to take measures:

If the Commission considers that a Member State has failed to fulfil an obligation under the Treaties, it shall deliver a reasoned opinion on the matter after giving the State concerned the opportunity to submit its observations. If the State concerned does not comply with the opinion within the period laid down by the Commission, the latter may bring the matter before the Court of Justice of the European Union. (TFEU, art. 258)

5 Article 258 mentions the three stages of the infringement procedure that the EC can engage against the state which has violated Community law: formal notice, reasoned opinion, and referral to the European Court of Justice (ECJ).

Different approaches in the literature on Europeanization identify a variety of elements that influence the transposition process of EU law in the domestic legal systems of member states (Kaeding, 2006; Thomson et al., 2007; Guigner, 2011). First of all, there are elements of European nature - such as the level of complexity of the directive, the time limits imposed, and the nature of the directive - as well as the kind of decision process. Secondly, there are national factors - administrative or institutional - which also influence the conduct that European states will adopt in the transposition and implementation of European law (Keading, 2006). Finally, the same literature supports 
the hypothesis that State compliance with European law depends on the "preference" shown by national governments in relation to directive provisions and the degree of freedom it leaves to states as for its implementation (Thomson et al., 2007, p. 688).

7 In its follow-up and control activities, the EC mobilizes strategies that follow four types of logic: sanction, positive incentives, persuasion and litigation (Börzel, Cichowski, 2003). However, the Commission exercises discretion in its actions: it can choose among these different options. This choice is exercised on the basis of preferences that the EC manifests with regard to the implementation of a national interpretation of European legislation (Steunenberg, 2010) 5 . Also, the approach of the Commission partly depends on the presence or the absence of political support from other states to initiate an infringement procedure. Faced with considerable opposition of states ${ }^{6}$ or the inability to mobilize their support, the Commission may choose not to initiate the infringement procedure (ibid.). Finally, the EC can initiate this procedure when "the non-compliance has become prominent enough for the Commission to be able to point out and to justify the necessary action" (Thomson, 2007, p. 686-687).

8 As such, the infringements that the Commission takes up do not cover the totality of infringements committed by EU member states. The infringement cases to which the EC reacts are either cases upon which the Commission acts on its own initiative or cases brought forward by companies or individuals who undertake actions against a state which does not transpose European directives into its national law (Tallberg, 2002)7. Moreover, infringement cases can also stem from investigation procedures initiated by the European Parliament, which can present it to the EC by exercising its right of inquiry ${ }^{8}$. Article 2, paragraph 1 of the 19 April 1995 Decision stipulates that

[...] the European Parliament may, at the request of one-quarter of its Members, set up a temporary committee of inquiry to investigate alleged contraventions or maladministration in the implementation of Community law which would appear to be the act of an institution or a body of the European Communities, of a public administrative body of a Member State or of persons empowered by Community law to implement that law. (TFEU)

9 The same Decision establishes that, within a period of two months after the Commission has been

[...] informed of an allegation made before a temporary committee of inquiry of a contravention of Community law committed by a Member State, the Commission may notify the European Parliament that a matter to be examined by a temporary committee of inquiry is the subject of a Community prelitigation procedure. (TFEU)

It is also important to note that the verbal forms used in this Decision, in its article 3, as well as in article 258 of the TFEU, concede a margin of discretion to the Commission and do not bind it to formally act: respectively, "the Commission may notify the European Parliament" and "if the Commission considers that a Member State has failed to fulfil one of its obligations". 


\section{Transposition and implementation of European law: non-compliance by states and action strategies of the European Commission}

11 This section outlines the system of management, monitoring, and control put in place at European level to frame EC actions against states that violate European law. It also focuses on EC strategies of action to ensure the compliance of states to European law.

As it has been previously mentioned, the non-compliance of European states with the transposition and implementation of European directives is the subject of annual reports published by the EC on the application of European Union law. In its $29^{\text {th }}$ Report published at the end of $2012^{9}$, it described the results obtained after the application of new instruments implemented in September $2011^{10}$. It was expected that these results contribute to a better implementation of EU law by member states. When the EC analyses the implementation of Community legislation, it focuses on member state behaviour in relation to the transposition process of European directives. This might be justified by the fact that late transposition of these directives leads to shortcomings in fulfilling obligations by states (Commission, 2012, p.3). The Commission is also interested in the inaccurate or incomplete transposition of European directives, as well as their inaccurate implementation (ibid., p. 6).

In its 2012 Report, the EC stressed that a significant increase could be observed in the number of infringements for 2011 with regard to the transposition procedure of European directives (ibid.) $)^{11}$. The increase is exactly $60 \%$ compared to 2010 (ibid., p. 3) year during which, there was an approximate 30\% decline in comparison with 2009 (Commission, 2011, p. 3). If, for 2010, Community law infringements were related to areas such as environment, internal market, and taxation (ibid., p. 4), in 2011, the most affected areas were transport, internal market, services, health and consumers (Commission, 2012, p. 5).

14 The attention given by the Commission to the implementation of European law by member states dates back to 2007 when it committed to putting in place preventive measures to promote more effective management of the implementation of Community law in member states (Commission, 2011, p. 13). In 2008, a new instrument, "EU-Pilot", was implemented to find solutions to the challenges faced by states while transposing European directives (ibid., p. 8). At the end of 2011, the reform was finalized, and the EU-Pilot instrument was adopted by 25 of the 27 states (Commission, 2012, p. 8).

The measures taken in reference to the EU-Pilot instrument refer to the management strategies that exist at European level and which aim at ensuring states' compliance. It is important to note that the system used at European level to ensure compliance is attributable to the interaction between two logics: implementation and management (Tallberg, 2002; Börzel, Cichowski, 2003). The system is present in both centralized and decentralized dimensions (Tallberg, 2002). In its centralized dimension, the managerial logic of the system is based on instruments such as European funds, transitional arrangements, cooperation between administrative authorities of member states and interpretative guidelines (ibid., p. 615).

16 In its article 258, the EU Treaty provides the three stages of the infringement procedure that the EC can use in the event that member states transgress European directive implementation. The three steps of this procedure - formal notice, reasoned opinion 
and referral to the ECJ - are intended to "increase pressure, making compliance an increasingly attractive option for member states" (ibid., p. 617). During these phases, in the same vein of "increasing pressure", the EC also resorts to press releases or regular reports (ibid.). If negotiation strategies do not produce positive effects, then referral to the ECJ remains the ultimate option to which the EC can resort. In addition, if the situation reaches this final stage, states are also subjected to financial penalties established in article 228 of the 1993 European Union Treaty (ibid., p. 618-619).

The normative fundamentals of the decentralized system are found in two fundamental principles framed by the ECJ: the "principle of direct effect" and the "principle of EU law supremacy", which confer to individuals and companies the right "to refer to the European dispositions directly in national courts" (Tallberg, 2002, p. 620). The same courts may request, when necessary, clarifications from the ECJ on the procedure.

In its centralized and decentralized dimensions, the EC uses four types of strategies or mechanisms to ensure the management, monitoring, and control of infringements: "penalty (the negative incentives), capacity building (the positive incentives), persuasion (learning) and the legal internalization (litigation)" (Börzel, Cichowski, 2003, p. 197). Nevertheless, Börzel and Cichowski believe that their effects and efficiency remain hardly measurable empirically. Though, these strategies imply that any choice made by the EC among these strategies depends on the persistence of the infringement and is proportionate to the number of resistant states (ibid., p. 198). Depending on the type of research conducted, researchers argue that the high number of states that resist changing may lead to different responses from the EC. Either the Commission can act in a more intrusive manner by appealing to litigation (ibid.); or it can choose to gloss over it and do nothing (Steunenberg, 2010). This last choice can be justified when referral to the Court of Justice could involve high cost and risks for the EC, namely the effort that it must deploy to present the case, but also the negative consequences on the EC's reputation in the event of judgment in favour to states (ibid., p. 371).

Briefly in terms of control, monitoring and management of infringements by European states, the authority of the European Commission is consolidated under two bases. On one hand, this authority derives from the European legal framework, more specifically the prerogatives that the member states have conferred to it through articles 297 and 258 of the TFEU. On the other hand, the authority of the EC is consolidated on non-legal bases which build on its policy leeway and the discretion that it enjoys in selecting infringements it deals with.

\section{European Commission press releases: authoritative discourse and purposes}

20 As shown by Tallberg (2002) and Steunenberg (2010), EC press releases are instruments of political pressure on states that have committed an infringement. We argue that this interpretation of press releases must be complemented by two key aspects that guide this analysis.

21 First of all, it is useful to analyse these press releases in terms of "reputation risk" (Gaultier-Gaillard, Pratlong, 2011, p. 273). With respect to European states confronted with an authoritative discourse of the EC, the use of this concept, mainly related to 
economics ${ }^{12}$, provides further insights. The concept can highlight the negative effects that this discourse can bring to state image, but also in relationships of trust with peers (Scott, Walsham, 2005). The effects on the image of actors can also be reverse analysed. In our case, it concerns the effects that these press releases can have on the Commission's image and credibility before member states, but also before European populations. Charaudeau (2011) highlights the fact that in any contextual political declaration, involving both a political forum and a civic forum, the political forum resorts to various rationalizing strategies. These rationalizing strategies of the political actor are oriented according to two logics which aim at "building up a picture of itself, so as to be credible in the eyes of the citizen forum (credibility ethos), on the one hand and, on the other hand, to be attractive (identification ethos); presentation of values, so that the citizen adheres to the same values enthusiastically" (ibid., p. 105).

Secondly, the relationship established between the EC and the member states is not a traditional one established between a donor and its beneficiaries, where the European donor simply targets the achievement of optimal results in terms of compliance with the European principles. This objective is part of a wider game between the European donor and its beneficiaries, in which "structures [...] must participate in spreading out a world vision consistent with the interests or beliefs of their donors" (Charlier, 2007, p. 113). In light of these aspects, we would argue that EC press releases are political authoritative discourses, which fit together as a set of contents of normative, organized, and structured character.

\section{Press releases and authoritative discourse}

23 To better grasp the trends of the Commission's authoritative discourse, we analysed 77 press releases published between September 2011 and September 2013 and available through an online database ${ }^{13}$. The selection of our corpus of analysis was made by applying three criteria: the period, the key term and the policy area ${ }^{14}$. As a first step, we selected EC press releases on the basis of the chosen period, which corresponds to the finalization of the process of the infringements management reform initiated in $2007^{15}$ by the Commission (September 2011), and respectively, to the beginning of this research (September 2013). After this first selection, a database of 10,082 press releases was considered. In a second phase, we used the key concept of "infringement procedure" as the selection criterion. This expression was applied for the three areas mostly concerned by state infringements committed during the chosen period: internal market and services, environment, judicial cooperation and fundamental rights ${ }^{16}$. Thus, among the 77 press releases selected as our basis for qualitative analysis, 18 press releases are related to judicial cooperation and fundamental rights, 23 to environment, and 36 to internal market and services.

24 Analysis of the EC's arguments in the three areas reveals that, in terms of communicational objectives, the Commission chooses to transmit information that highlights the states' lack of compliance with the process of transposition and implementation of European legislation. The lack of compliance is illustrated by four elements, systematically presented through an example taken from our corpus of analysis:

- Lack of harmonization between domestic and European laws. For example, a press release from 27 October 2011 related to the environment explains: 
The directive should have been transposed into domestic law on 26 December 2010. However, 11 countries have not yet proceeded to its transposition to this day and the Commission has delivered reasoned opinions to eight of them, namely, Germany, Cyprus, Greece, Italy, Lithuania, Malta, Portugal, the Czech Republic and Slovenia. ${ }^{17}$

- Incomplete implementation of European directives. A press release in the same area issued on 27 October 2011 notes that

[...] the Commission has identified several gaps in the transposition of EU legislation on the waste management of extractive industries in the Polish legislation. ${ }^{18}$

- Existence of national procedures which impede the implementation of fundamental principles of the EU. In a press release on judicial cooperation and fundamental rights issued on 17 January 2012, it is mentioned:

[...] the Hungarian legislation is contrary to the Union's law since it questions the independence of the Central Bank and of data protection national bodies and includes measures affecting the judicial system. ${ }^{19}$

- Possible violation of European commitments of national authorities subject to EU Treaty rules. A press release in the same area notes on the 21 June 2012 that:

The European Commission has established a deadline of two months to Austria, Germany, and Sweden to comply with the rules of the European Union related to the free movement of citizens of the Union and their family members on the EU's territory. ${ }^{20}$ breached and it highlights the need for its implementation. Finally, deadlines for 
response are indicated to the states that have committed an infringement in relation to Community law:

The Hungarian authorities have now one month to respond to the concerns raised by the Commission..$^{24}$

In the absence of a satisfactory reply within two months, the Commission may refer these countries to the European Court of Justice. ${ }^{25}$

On the other side, another type of press release can be identified. It concerns declaration which has a "rewarding" nature, in which the Commission closes the infringement procedures initiated against some member states. For example, in a press release of 27 February 2012:

The European Commission is pleased that Greece has transposed into its domestic law the directive of the European Union on the compensation of victims of crime. Greece has complied with the judgment of the Court of Justice of the European Union of 31 March 2011 and has paid a fine of three million Euros to the Commission for not having taken into account an earlier judgment of the Court for non-transposition of EU rules. The Commission therefore puts an end to the infringement proceedings against Greece. ${ }^{26}$

These press releases often include official statements from key EC actors, as well as the history of the infringement. This type of political speech might have two supplementary objectives: on the one hand, it might be a reward granted to member states which finally conformed to the line of conduct set by the EC; on the other, it might be a Commission strategy aimed at demonstrating to the public that its authority has finally prevailed.

\section{Press releases and authoritative discourses}

By reaffirming the respect of principles through its press releases, the EC first seeks to sanction the state which, voluntarily or not, violates European law. The press release then becomes an instrument of control or sanction which can imply the same costs, for the state, in terms of political credibility and reputation, as the use of other legal procedures ${ }^{27}$. Thus, the press release fulfils two functions at once: sanction and persuasion/deterrence. Sanctioning the infringing state has a persuading effect on other states to follow the conformity track to EU law and, vice versa, to deter them from not doing so. The Commission's press release is primarily a "political discourse [...] where what counts more is not the truth of this speech publicly pronounced, but its power of persuasion, its veracity" (Charaudeau, 2011, p. 105 - we underline). The important part to understand is the social force that the homogeneous discourse of EC press releases may present. Persuasion should be here understood as a force of "seduction or even manipulation" (Amossy, Koren, 2010, p. 17) exerted by the EC on target audience.

Finally, EC press releases can play the role of a strategic tool questing legitimacy: "From the beginning of the nineties, the Commission is in quest for legitimacy" (Gautron, 2012, p. 30). This quest for legitimacy continues even after the adoption of the Lisbon Treaty, given persistent criticism on the EC's "democratic deficit" 28 (ibid.). These criticisms are indicative of the presence "of a direct crisis of legitimacy [...] but also an indirect crisis of legitimacy" 29 of the EC. In this sense, the European Commission uses the press release to legitimize its action and reaffirm the legitimacy of the European project before European citizens. In fact, what may seem to be an explanatory exercise 
is a quest for authoritative legitimacy before them. Furthermore, the legitimization of the European project on the European arena presents a constant interest for the EC. Even "during informal consultations ${ }^{30}$ at preliminary stages the Commission draws on arguments of effectiveness and legitimacy of European law to persuade member states to comply with it" (Börzel, Cichowski, 2003, p. 208).

On the other side, through its press releases, the EC seeks to reaffirm its authority and to consolidate its power within the institutional architecture of the European Union, at a time when its power is partly weakened. Since the Lisbon Treaty, the European Commission has reached a specific institutional context characterized by the reconfiguration of competences of the European Parliament and the European Council. That is the "EU's parlementarisation" (Bauer, Ege, 2012, p. 431) and the "gouvernementalisation of the Council structure" (ibid.). The "EU's parlementarisation" consists of strengthening the political influence of the European Parliament over the EC through its new role in defining the European political agenda, confirming candidates for the position of commissioner and approving committees ${ }^{31}$. On the intergovernmental side, the European Council's role was also strengthened and has become "a formal European institution" (ibid.). Whereas previously, the "monopoly of initiative" belonged to the European Commission, this is no longer the case since Lisbon. Therefore, the European Council may also define "detailed strategic programmes that other institutions must then "implement" (ibid.). In addition, managing the economic crisis in some European states and the political crises in Georgia and the Arab countries has favoured the strengthening of the European Council to the detriment of the European Commission (Quermonne, 2011). Moreover, the presence of some states on the European scene during the economic crisis period, through either leadership practices or populist and nationalist practices, was a constant to the expense of the EC. The EP's "parlementarisation" and the Council's "gouvernementalisation" puts the European Commission "more and more [...] on the sidelines" (Bauer, Ege, 2012, p. 431).

However, in spite of these challenges analysed in terms of pressures ${ }^{32}$ originating from either some member states, the Council, or even the Central Bank ${ }^{33}$, the European Commission is moving toward a process of "presidentialisation" of its structure (ibid.). Changes of the Commission's roles can be identified: the consolidation of the authority of the EC President on internal organization level (1) or the internal institutional reforms with regard to either building directional capacities or redeveloping technocratic and political structures of the institution ${ }^{34}$ (2) (ibid., p. 432). The establishment of the European semester and new structures in economic, banking and financial governance play the same role (Quermonne, 2011). This process of internal reform and redefinition of organizational capacity demonstrates that the European Commission is not unified, and illustrates an "indirect crisis of legitimacy" (Gautron, 2012, p. 30), which would result in the "quest for a configuration or a structure that better reflects its true identity" (ibid.).

In this context of institutional transformations, the ability of the European Commission to have things done or to impose a certain way of doing is undermined by pressures from member states. Lack of transposition of European law can be the manifestation of these pressures. The press releases are used as a tool for reaffirming the authority and power of the EC. Power consolidation by the EC is manifested through actions that the Commission undertakes to encourage states to transpose and implement European 
directives ${ }^{35}$. Through the claim of neutrality, the authoritative discourse constantly used by the EC is supposed to emphasize that the Commission is only exercising the prerogatives of its mission in a non-arbitrary way. This is the defense of fundamental values of the European Union, such as freedom of movement, independence of the judiciary system and national banking institutions, respect of the rule of law whose violation would jeopardize the link that unites the members of the European project. In addition, its authoritative discourse is built on normative arguments relating to the obligation for each European state to transpose European legislation, presented under the form of directives, into domestic law.

This paper proposed to interpret the normative nature, as well as the structured and organized character of EC political discourses regarding the non-compliance of European states with the process of transposition and implementation of EU law. This interpretation has allowed us to identify other functions that these press releases may fulfil, apart from putting pressure on non-complying states.

The relationship between the EC and ember states is not a relationship in which the European donor aims simply at promoting the respect of European principles. The respect of these principles also involves a process of dissemination of a certain global European vision through which the Commission tries to ensure that the fundamentals of its project are non-questionable.

The paper considers EC press releases as specific discourses. These are instruments belonging to a European system of control and monitoring of state infringements. Publically, they constitute a strategy of denunciation. The analysis of 77 press releases, from the 2011-2013 period, highlighted that they are characterized by an authoritative style and that they form a homogeneous set whose content has a normative, organized and structured character. In the discourse promoted, the Commission aims at defending and imposing the respect of the EU's fundamental values through strategic actions which encourage states to implement European directives in accordance with the clauses of the Treaty. The non-implementation of these guidelines is considered as transgression subject to an infringement procedure. Infringements identified are mainly the non-transposition and the lack of implementation of the directives, as well as the incompatibility between national and European legislation. This is a lack of implementation of the European game rules initially accepted by all the players. This non-compliance with the rules is the equivalent to challenging the fundamentals of the European project.

In fact, apart from other heterogeneous elements - formal notices, reasoned opinions, disputes, reports, reforms, different instruments-, press releases are part of a relatively homogeneous system of the organization. It is a centralized and decentralized system of control and management progressively implemented by the Commission to manage the non-compliant behaviour of member states. These different elements are supposed to guide the conduct of member states according to a given context. This framework, which was initially planned in the various treaties of the European Union, has been adapted over time by the EC in consultation with other institutional actors, such as the Council, Parliament, and governmental actors. The modulation of the framework is made through joint decisions, reforms introduced, etc. 
EC press releases can present different strategic objectives. First of all, they are used to sanction the states that violate European law. This penalty mechanism involves costs related to political credibility and reputation of the states that violate European regulation. Then, the force of the press releases is in their power to persuade other member states to conform to European law. They then become dissuasion tools for other states. Finally, they are strategic tools through which the EC seeks its legitimacy before European populations. The Commission thus seeks to confirm its authority and to consolidate its power in the context where they are weakened by the nonimplementation of EU law by member states.

\section{NOTES}

1. To date, the European Commission has published 29 annual reports on the status of the implementation of Community law by the member states. The $29^{\text {th }}$ Report dates from 30 November 2012. See the complete references at the end of this paper.

2. European Commission, 28th Annual Report on monitoring the implementation of European Union law, Brussels, 29 September 2010, p. 2 (idem).

3. "A political discourse is any discourse that is part of a communication activity (press conference, debate, partisan speech, etc.) whose conjunction of the space-temporal framework, the statute and roles of actors, the objectives and actions, result in potential political impacts." (Chanay, Turbide, 2011, p. 5).

4. Consolidated version of the EU Implementation Treaty, Official Journal of the European Union, C83/47, 30 March, 2010.

5. The choice of accepting the national interpretation of the European legislation can be explained by the fact that this legislation is the result of a power relationship between the Council, the European Parliament, and the Commission. The balance of power will tilt in favour of one of these three actors. See also Kaeding (2006) and Thomson et al. (2007).

6. This is a variable relative to the number of states.

7. This is the "decentralized compliance system" which gives companies and individuals the right to consult national courts when states violate the European law.

8. See the Decision of the European Parliament, the Council and the Commission of 19 April 1995 which retains the conditions under which the European Parliament can exercise the inquiry right (online).

9. $29^{\text {th }}$ Annual Report on monitoring the implementation of European Union law, doc. cited.

10. $28^{\text {th }}$ Annual Report on monitoring the implementation of European Union law, doc. cited. 
11. $2^{\text {th }}$ Annual Report, doc. cited. In decreasing order, Poland (46 infringements), Czech Republic (41), Belgium (40), Cyprus (39), Italy (39), Austria (37), Greece (37), Finland (37), Great Britain (36), and Slovenia (32) occupy the first ten places.

12. The concept of "reputation risk" appeared at the end of the sixties and has been developed from the nineties in the field of organizational theories and management of corporate image. See Gaultier-Gaillard, Pratlong (2011) and Scott, Walsham (2005).

\section{See: http://europa.eu/rapid/search-result.htm?locale=FR}

14. http://europa.eu/rapid/search.htm?refine=1

15. 25 of the 27 member states had then adopted the new dialogue instruments with the EC, more specifically the EU Pilot instrument.

16. European Commission, 29 September 2010, doc. cited, p.4. See also European Commission, "Smart tools improve the application of EU law", Brussels, 29 September 2011.

17. "Crimes affecting environment: the Commission continues to pursue the Member States." Press Release (PR), Brussels, 27 October 2011.

18. "Environment: the Commission urges Poland to comply with the EU legislation on waste." PR, Brussels, 27 October 2011.

19. "The European Commission opens an accelerated infringement procedure against Hungary concerning the independence of its central bank and its instances of data protection and regarding specific measures related to its judicial system." PR, Brussels, 17 January 2012.

20. "Free movement: the Commission invites Austria, Germany, and Sweden to respect the rights of citizens of the Union." PR, Brussels, 21 June 2012.

21. "The European Commission introduces an accelerated infringement procedure against Hungary concerning the independence of its central bank and its instances of data protection and regarding some specific measures related to its judicial system." PR, Brussels, 27 January 2012.

22. "Consumption: the European Commission is taking action to enforce the provisions of protection in terms of timesharing." PR, Brussels, 29 September 2011.

23. "The European Commission introduces an accelerated infringement procedure against Hungary concerning the independence of its central bank and its instances of data protection and regarding specific measures related to its judicial system." PR, Brussels, 17 January 2012.

24. Ibid.

25. "Crimes affecting environment: the Commission continues to pursue the Member States." PR, Brussels, October 27, 2011.

26. "Compensation of victims of crime: Greece complies with the judgment of the Court of Justice and adopts the legislation of the EU." PR, Brussels, 27 February 2012.

27. For more information on the effects of the use of legal procedures on the states which do not transpose Community law, see Börzel, Cichowski (2003).

28. This is a recurring problem which affects the institutional structure in Europe, not only the European Commission.

29. See Gautron, 2012, respectively p. 30-33 and p. 34-38. 
30. Informal negotiations remain confidential and they are not analysed enough (Börzel, Cichowski, 2003).

31. See also Gautron (2012, p. 29-30), who stresses that apart from the provisions of the Lisbon Treaty on initiative power sharing with the European Parliament, the competence of the European Commission is also limited in the field of foreign policy and community security.

32. See Quermonne (2011) and Bauer, Ege (2012).

33. The role of the Central Bank was strengthened during the economic crisis. See Quermonne (2011).

34. The "Kinnock" reforms are part of this process. See Bauer, Ege (2012, p. 432-433).

35. We refer here to Bourgeois and Nizet's (1995) definition of power. Power is exercised when an individual has the capacity to make another individual do things that otherwise he would not do. This capacity takes the form of attempts to influence without insisting on hierarchy, but on the type of relationship established between individuals (p. 20-21).

\section{ABSTRACTS}

This paper aims to identify the authoritative discourse that the European Commission adopts in its political discourses related to the process of transposition and implementation of European law by member states. Through the analysis of European Commission press releases, the paper identifies the purpose that appears to be targeted by these press releases.

\section{AUTHOR}

OANA MARINA PANAIT

Université catholique de Louvain 